\title{
Erratum to: Can foreign aid reduce income inequality and poverty?
}

\author{
Alberto Chong • Mark Gradstein · Cecilia Calderon
}

Published online: 1 April 2011

(C) Springer Science+Business Media, LLC 2011

Erratum to: Public Choice (2009) 140: 59-84

DOI 10.1007/s11127-009-9412-4

This article is an adaptation of Calderón, C., Chong, A. \& Gradstein, M. Foreign aid, income inequality and poverty. Inter-American Development Bank working paper \#547, 2006.

The online version of the original article can be found under doi:10.1007/s11127-009-9412-4.

\footnotetext{
A. Chong $(\bowtie)$

e-mail: albertoch@iadb.org

M. Gradstein

Ben Gurion University, Beersheba, Israel

C. Calderon

University of Pennsylvania, Philadelphia, PA, USA
}

Inter-American Development Bank, 1300 New York Ave. NW, Washington, DC 20577, USA 